\title{
Flowers visited by hummingbirds in the open habitats of the southeastern brazilian mountaintops: species composition and seasonality
}

\author{
Rodrigues, LC. ${ }^{a *}$ and Rodrigues, $M^{a}{ }^{a}$ \\ a'Laboratório de Ornitologia, Departamento de Zoologia, Instituto de Ciências Biológicas - ICB, \\ Universidade Federal de Minas Gerais - UFMG, CP 486, CEP 31270-901, Belo Horizonte, MG, Brazil \\ *e-mail: licleia@yahoo.com.br
}

Received: April 4, 2013 - Accepted: May 9, 2013 - Distributed: August 31, 2014

(With 5 figures)

\begin{abstract}
The hummingbird-visited plant community located on the open-habitat mountaintop of the Espinhaço Range was studied

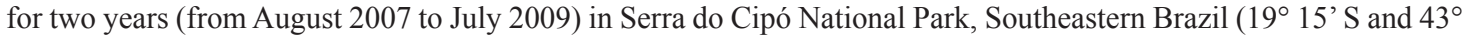
$\left.31^{\prime} \mathrm{W}\right)$. The floral characteristics and flowering period of the hummingbird-visited plants was monthly recorded along trails located in three vegetation types: (1) typical campos rupestres (TCR), (2) open fields (OPF), and (3) capões de mata (CAM). Hummingbird visitation was observed in 51 plant species, 22 ornithophilous and 29 non-ornithophilous species. The TCR showed the greatest number of species visited $(\mathrm{N}=38)$, followed by the OPF $(\mathrm{N}=18)$ and CAM $(\mathrm{N}=17)$. Six species of hummingbirds were recorded visiting flowers: Augastes scutatus, Campylopterus largipennis, Colibri serrirostris, Chlorostilbon lucidus, Eupetomena macroura and Phaethornis pretrei. This study demonstrates that the species richness and the number of ornithophilous species visited by the hummingbirds at the study site are more similar to hummingbird-plant communities of the Atlantic Forest than to those of the Cerrado communities and other Brazilian highland open-habitat communities. The plant families most visited by hummingbirds were Bromeliaceae and Asteraceae. Although the Asteraceae family is rarely used as a food resource for hummingbirds in other high and lowland communities, in the study site this family is used mainly by the endemic hummingbird Augastes scutatus. We found a large overlap of flowering throughout the year among the species visited by the hummingbirds. Thus, the nectar availability supports these resident hummingbirds. The present study also showed that the studied hummingbird-plant community is composed of many species endemic to the campos rupestres of the Espinhaço Range, some of which are considered to be in danger of extinction, thus constituting a unique and threatened community. Thus, understanding hummingbird-plant pollination dynamics becomes fundamental to the conservation of the campos rupestres.
\end{abstract}

Keywords: plant community, campos rupestres, flowering phenology, hummingbirds, pollination syndromes.

\section{Flores visitadas por beija-flores em habitats abertos de montanhas do sudeste do Brasil: sazonalidade e composição de espécies}

\section{Resumo}

A comunidade de flores visitadas por beija-flores em habitats abertos de montanhas da Serra do Espinhaço, sudeste do Brasil foi estudada por dois anos (de agosto de 2007 a julho de 2009) no Parque Nacional da Serra do Cipó (19 $15^{\prime} \mathrm{S}$ e $43^{\circ}$ $\left.31^{\prime} \mathrm{W}\right)$. As características florais e o período de floração das plantas visitadas foram registradas mensalmente ao longo de trilhas localizadas em três tipos vegetacionais: (1) campos rupestres típicos (TCR), (2) campos abertos (OPF), e (3) capões de mata (CAM). Foram observadas visitas de beija-flores a 51 espécies de plantas: 22 ornitófilas e 29 não-ornitófilas. O TCR apresentou o maior número de espécies visitadas $(\mathrm{N}=38)$, seguido pelo OPF $(\mathrm{N}=18)$ e CAM $(\mathrm{N}=17)$. Seis espécies de beija-flores foram observadas visitando as flores: Augastes scutatus, Campylopterus largipennis, Colibri serrirostris, Chlorostilbon lucidus, Eupetomena macroura e Phaethornis pretrei. A riqueza de espécies e o número de espécies ornitófilas visitadas pelos beija-flores, neste estudo, foi mais similar à comunidades de plantas visitadas por beija-flores na Floresta Atlântica, que as comunidades do Cerrado, bem como de outras comunidades de ambientes abertos do Brasil. As famílias com maior número de plantas visitadas pelos beija-flores foram Bromeliaceae e Asteraceae. Apesar da família Asteraceae, raramente ser utilizada como fonte alimentar pelos beija-flores em outras comunidades, nas áreas amostradas neste estudo esta família foi utilizada, principalmente, pelo beija-flor endêmico A. scutatus. Nós registramos grande sobreposição de floração ao longo do ano entre as espécies visitadas pelos beija-flores. Portanto, a disponibilidade de néctar mantem os beija-flores residentes. Este estudo, demonstrou também, que a comunidade de plantas visitadas pelos beija-flores nesta área é composta por muitas espécies endêmicas dos campos rupestres da Serra do Espinhaço, algumas das quais consideradas em perigo de extinção, constituindo assim uma comunidade única e ameaçada. Portanto, o entendimento da dinâmica de polinização desta comunidade é fundamental para a conservação dos campos rupestres.

Palavras-chave: comunidade de plantas, campos rupestres, fenologia de floração, beija-flores, síndromes de polinização. 


\section{Introduction}

Flowers adapted to hummingbird pollination are an important component of Neotropical plant communities, comprising $2 \%$ to $15 \%$ of angiosperm species in a given community (Feinsinger, 1983; Machado and Lopes, 2004; Ramírez, 2004; Rodrigues and Araujo, 2011). On the one hand, hummingbird-pollinated flowers show morphological and ethological adaptations that include a prevalence of red colour, a narrow tubular shape, incline position, lack of landing platforms, diurnal anthesis and large quantities of diluted nectar (Faegri and Pijl, 1980; Wilson et al., 2004; Machado and Rocca, 2010). On the other hand, hummingbirds are a group of specialised and highly aerial birds (Bleiweiss, 2009) endemic to the Americas, with high diversity in the Andes and in the highlands of southeastern Brazil (Stotz et al., 1996). Hummingbirds are the largest group of vertebrate pollinators in the Neotropics (Bawa, 1990).

Many studies have shown that hummingbirds are generalists with respect to their use of floral resources as dietary supplements, including varying percentages of flowers supposedly adapted to pollination by other groups of animals (Araujo, 1996; Araujo and Sazima, 2003; Machado, 2009; Machado and Rocca, 2010, Rodrigues and Araujo, 2011). The communities of plants used as food resources for hummingbirds have been relatively well studied in forests and savanna habitats of Brazil (see Rodrigues and Araujo, 2011 and Araújo et al., 2011).

The montane open habitats in southeastern Brazil are recognised as important centres of endemism for Neotropical flora and fauna (Giulietti et al., 1997; Safford, 1999; Silva and Bates, 2002; Echternacht et al., 2011; Vasconcelos and Rodrigues, 2010). These open habitats include the campos rupestres scattered along the Espinhaço Range and the campos de altitude in the mountains of the Serra do Mar, Serra da Mantiqueira, and associated ranges (Giulietti et al., 1997; Safford, 1999).

The campos rupestres is located at above $900 \mathrm{~m}$ altitude and are mainly associated with outcrops of quartzite, sandstone and iron ore (Vasconcelos, 2011). The campos de altitude are located at approximately $1,500 \mathrm{~m}$ in altitude and are associated with igneous or metamorphic rocks, such as granite and gneiss (Vasconcelos, 2011). The campos rupestres of the Espinhaço Range are located in the areas of contact between the Cerrado, the Caatinga and Atlantic Forest, whereas the campos de altitude are fully inserted into the Atlantic Forest domain (Giulietti et al., 1997; Safford, 1999). Although both of these open habitats present similar landscapes and share similar genera and species of plants, these two types of vegetation show differences in the biogeographic affinities of their flora (Giulietti et al., 1997; Safford, 1999; Alves and Kolbek, 2010). A previous study conducted in the open-habitat mountaintops showed that hummingbird pollination is surprisingly uncommon in campos de altitude (Freitas and Sazima, 2006), in contrast with studies that have reported a high number of hummingbird-pollinated plant species in campos rupestres (Vasconcelos and Lombardi, 2001; Machado et al., 2007).

The present study examines a hummingbird-flower community located on the open-habitat mountaintop of the Espinhaço Range of southeastern Brazil. Thus, the aim of the study is to achieve the following goals: (1) to record the species richness and taxonomic composition of hummingbird-visited plants, independently of their supposed syndrome, in three habitats of the Espinhaço Range; (2) to characterise the floral morphology of these plants; (3) to investigate the availability of floral resources for hummingbirds; and (4) to determine the pollinator species among hummingbird-pollinated plants and the behaviour of these birds during pollination. We expect to establish a baseline dataset to contrast our findings with those published previously.

\section{Material and Methods}

\subsection{Study site}

This study was conducted in a region known as the Alto do Palácio (hereafter AP, $19^{\circ} 15^{\prime} \mathrm{S}$ and $43^{\circ} 31^{\prime}$ $\mathrm{W}$, at approximately $1350 \mathrm{~m}$ above sea level), which is located in the northern part of the Serra do Cipó National Park (SCNP) and comprises the southern portion of the Espinhaço Range (Rodrigues et al., 2005).

The AP region is located in the eastern portion of Serra do Cipó and is characterised by a campos rupestres habitat and the strong influence of certain vegetation that is typical of the Atlantic Forest biome. In this region, the landscape is described as a mosaic consisting of the following habitats: (1) typical campos rupestres (hereafter TCR), which are areas of rocky outcrops with herbaceous vegetation and shrubs; (2) open fields (hereafter OPF) composed predominantly of herbaceous species; and (3) capões de mata (hereafter CAM), which are small areas of dense forest-like vegetation associated with wetter areas. For more detailed description of habitats see Rodrigues and Rodrigues (2011).

The region experiences extreme variations in rainfall, with particularly wet summers (from November to January) and extremely dry winters (from June to September) (Figure 1, Rodrigues et al., 2011). Usually, there is a soil water deficit from May to August, which coincides with the coldest months of the year (hereafter referred to as the dry season). In the rainy season, which lasts from November to March, there is an excess of water in the soil coinciding with the warmest months of the year (Rodrigues et al., 2011).

\subsection{Data collection}

We made 24 trips to the AP, from August 2007 to July 2009 , for a total of 120 days of fieldwork. The flowering of hummingbird-visited plants (independent of their pollination syndrome) was recorded monthly, in trails measuring $10 \mathrm{~m}$ wide and $1,800 \mathrm{~m}$ in length, of which $1,200 \mathrm{~m}$ are located in the OPF and $600 \mathrm{~m}$ in the TCR (comprising a total sample area of $12,000 \mathrm{~m}^{2}$ in the OPF and $6,000 \mathrm{~m}^{2}$ 


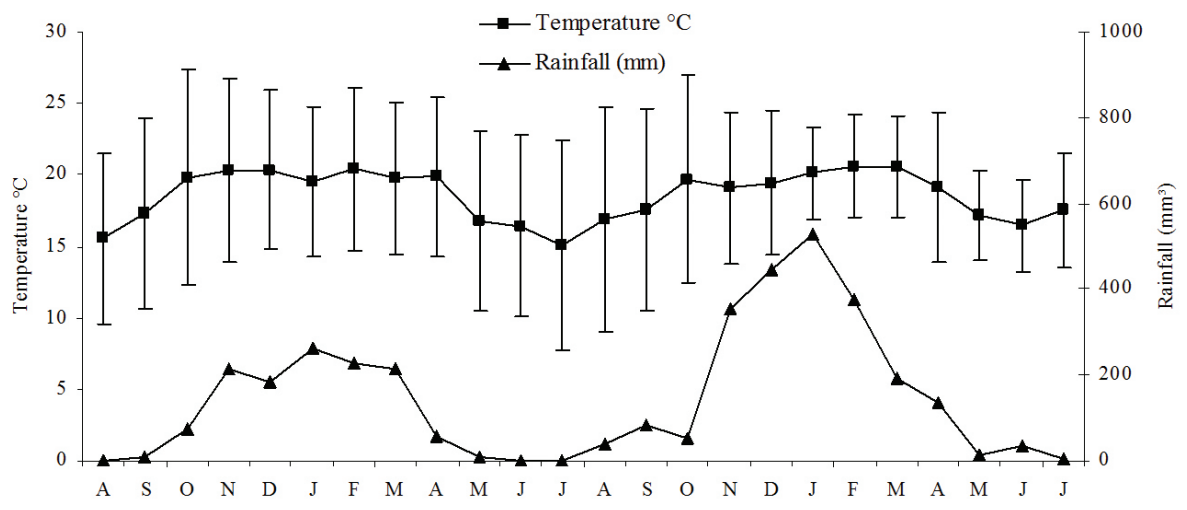

Figure 1. Monthly rainfall and mean temperature for Alto do Palácio, Serra do Cipó National Park, MG, southern Brazil. Data from August 2007 to July 2003.

in the TCR). The sampling in the CAM occurred during systematic walks along the forest edge and within two areas of the CAM (comprising a total sample area of 400 $\mathrm{m}^{2}$ ). The size of the area sampled in each of the distinct plant physiognomies reflects their representation in the AP.

Data concerning the growth form, numbers of open flowers per individual per day and floral characteristics (corolla shape, length and colour, concentration and volume of accumulated nectar) were recorded. The corolla effective length (sensu Wolf et al., 1976) and corolla diameter were measured in fresh flowers or material collected and fixed in $70 \%$ alcohol with a manual caliper. Voucher specimens from the plant species were deposited in the Herbarium of the Departamento de Botânica, ICB-UFMG (BHCB).

The pollination syndromes of the hummingbird-visited plants were determined using the predominant colours of corolla and bracts, the corolla morphology, the presence of odour, and the period of anthesis (see Rodrigues and Araujo, 2011). Typical ornithophilous species have odourless flowers with diurnal anthesis and tubular, red, pink, yellow or orange corollas (cf. Faegri and Pijl, 1980).

The remaining species visited by the hummingbirds were classified as non-ornithophilous. This non-ornithophilous species were further divided into mellitophilous (flowers adapted for bee pollination), sphingophilous (flowers adapted for sphingid pollination) and chiropterophilous (flowers adapted for bat pollination) species, according to the floral characteristics described by Faegri and Pijl (1980), and entomophilous, which is a species that can be pollinated by insects of two or more taxonomic groups. Additionally, four other species were classified as chiropterophilous-ornithophilous (flowers with transitional characteristics between the ornitophily and chiropterophily syndromes), according to the floral characteristics described by Sazima et al. (1994) and Sanmartin-Gajardo and Sazima (2005).

All flowering individuals potentially visited by hummingbirds were recorded. The phenological patterns of the species were categorised according to Newstrom et al. (1994). An analysis of variance (ANOVA) with a Tukey test $a$ posteriori was conducted to verify that the number of flowering species per month differed among distinct habitats.

The flower density was calculated monthly for each plant habitat using the total number of flowers per total sampling area (flowers $/ \mathrm{m}^{2}$ ) (Araujo, 1996). The flower density (flowers $/ \mathrm{m}^{2}$ ) was transformed to $\log (\mathrm{n}+1)$, and an ANOVA with a Tukey test a posteriori was conducted to verify that the flower density differed among the habitats. A Mann-Whitney U test was performed to compare the total density of the flowers per month between the ornithophilous and non-ornithophilous species.

The sugar concentration and volume of nectar were quantified in flowers and in Paliavana sericiflora Benth. (Gesneriaceae), also in flower buds, bagged the day before and measured between 10:00 and 13:00 $\mathrm{h}$ the following day. The nectar volume was measured using a Hamilton microsyringe, and the sugar concentration was measured using a Instrutherm pocket refractometer $0-32 \%$ ( $c f$. Galetto and Bernardello, 2005). Flowers that showed sugar concentrations higher than $32 \%$ had their volume diluted with a equal portion of water. The idealised sample size consisted of 20 flowers from three different individuals; however, intrinsic limitations of each species (such as the individual density of the study area and/or plants that produce only one flower every two or three days) and limitations of the study resulted in varied sample sizes. The sugar concentration and nectar volume were converted into $\mathrm{mg}$ of sugar/ $\mu$ l of nectar according to Galetto and Bernardello (2005).

Observations of hummingbird visitors were made monthly using a direct focal plant observed for 40 to 180 $\mathrm{min}$. The observations were recorded mainly between $06: 00$ AM-10:00 AM and 03:00 PM-06:00 PM. When possible, more than one focal individual was observed (modified from Rocca-de-Andrade, 2006). Casual observations of visits, the plant species visited and the species of hummingbird visitors were also noted. The visits were classified as 1) legitimate when the hummingbirds contacted the anthers and/or stigmas in a way that would result in pollination or (2) illegitimate when the hummingbirds did not contact the anthers and/or stigmas. The hummingbirds were identified by direct visual observations during their visits to flowers, 
and photographs were taken during the visits. The time, number of visits and behaviour of the hummingbirds during the visits were recorded. The occurrence and outcome of agonistic interactions between the hummingbirds were also recorded. Were considered as agonistic interactions, aggressive manifestations between hummingbirds, such as chasing or pecking (Machado and Rocca, 2010). Hummingbirds with evident sexual dimorphism were considered separately in the analyzes.

The hummingbird visit frequencies (number of flowers visited per plant min $^{-1}$ number of observed flowers ${ }^{-1}$ ) were transformed to $\log (n+1)$. A Mann-Whitney $U$ test was used to compare the hummingbird visit frequencies between the ornithophilous and non-ornithophilous flowers species.
An analysis of covariance (ANCOVA) was performed to determine whether the number of flowers observed and the category of plant species visited (ornithophilous or non-ornithophilous) affected the number of foraging bouts. These data were transformed to $\log (n+1)$.

\section{Results}

\subsection{Community composition of hummingbird-visited plants}

We recorded hummingbird visits to 51 plant species, considering subspecies and varieties separately (Table 1), of which $43.1 \%(\mathrm{~N}=22)$ were ornithophilous, $29 \%(\mathrm{~N}=15)$ were mellitophilous, $14 \%(\mathrm{~N}=7)$ were entomophilous,

Table 1. Volume and concentration of nectar accumulated and the amount of sugar in the nectar of the ornithophilous and non-ornithophilous species (in bold) visited by the hummingbirds in the Alto do Palácio, Serra do Cipó National Park, MG, southern Brazil. $\mathrm{X}=$ mean, $\mathrm{SD}=$ standard deviation and $\mathrm{N}=$ number of sampled flowers.

\begin{tabular}{|c|c|c|c|}
\hline \multirow[t]{2}{*}{ Species } & Nectar volume $(\mu \mathrm{L})$ & $\begin{array}{c}\text { Nectar Concentration } \\
(\%)\end{array}$ & Sugar in nectar (mg) \\
\hline & $\mathbf{X} \pm \mathbf{D P}(\mathbf{N})$ & $\mathrm{X} \pm \mathrm{DP}(\mathrm{N})$ & $\mathrm{X} \pm \mathrm{DP}(\mathrm{N})$ \\
\hline Aechmea lamarchei & $13.1 \pm 5(13)$ & $25.8 \pm 4.1(13)$ & $3.8 \pm 1.8(13)$ \\
\hline Agalinis angustifolia & $18.75 \pm 9.95(8)$ & $18.52 \pm 1.65(8)$ & $3.73 \pm 2.29(8)$ \\
\hline Agarista cariifolia & $1.6 \pm 1.8(18)$ & $17.1 \pm 3.1(18)$ & $0.2 \pm 0.3(18)$ \\
\hline Barbacenia flava & $45.2 \pm 36.37(5)$ & $18.36 \pm 1.32(5)$ & $9.1 \pm 7.59(5)$ \\
\hline Billbergia vittata & $21 \pm 5.83(5)$ & $22.08 \pm 0.85(5)$ & $5.03 \pm 1.57(5)$ \\
\hline Calolisianthus pendulus & $4.8 \pm 10.73(5)$ & $26(1)$ & $6.85(1)$ \\
\hline Dyckia sp.1 & $11.5 \pm 5.3(13)$ & $22.7 \pm 10.4(13)$ & $3.3 \pm 3.7(13)$ \\
\hline Esterhazya splendida & $29 \pm 1.73(3)$ & $17.06 \pm 1(3)$ & $5.2 \pm 0.61(3)$ \\
\hline Hololepis pedunculata & $7.5 \pm 1.91(4)$ & $23.5 \pm 1.91(4)$ & $1.94 \pm 0.64(4)$ \\
\hline Lobelia fistulosa & $60.33 \pm 10.1(3)$ & $16.6 \pm 0.52(3)$ & $10.51 \pm 1.76(3)$ \\
\hline Nematanthus strigillosus & $8.7 \pm 5.3(14)$ & $22.4 \pm 4.4(14)$ & $1.9 \pm 1.1(13)$ \\
\hline Neoregelia bahiana & $24.75 \pm 3.77(4)$ & $44.6 \pm 4.6(3)$ & $12.7 \pm 3.1(3)$ \\
\hline Siphocampylus fimbriatus & $22.2 \pm 15.73(5)$ & $19.92 \pm 1.26(5)$ & $4.85 \pm 3.52(5)$ \\
\hline Stachytarpheta glabra & $7.6 \pm 1.6(12)$ & $23.2 \pm 0.8(12)$ & $1.9 \pm 0.4(12)$ \\
\hline Stachytarpheta mexiae & $4.33 \pm 2.38(15)$ & $23.25 \pm 3.1(14)$ & $1.1 \pm 0.5(14)$ \\
\hline Vriesea procera var. procera & $36 \pm 16.97(2)$ & $23.1 \pm 1.27(2)$ & $8.88 \pm 3.69(2)$ \\
\hline Vriesea procera var. tenuis & $61.5 \pm 10.6(2)$ & $22.3 \pm 0.99(2)$ & $14.86 \pm 3.28(2)$ \\
\hline Encholirium subsecundum & $8.52 \pm 0.26(4)$ & $13.7 \pm 0.38$ & $1.21 \pm 0.05(4)$ \\
\hline Eremanthus crotonoides & - & - & - \\
\hline Eremanthus erythropappus & - & - & - \\
\hline Gaylussacia brasiliensis & - & - & - \\
\hline Gaylussacia hispida & - & - & - \\
\hline Gaylussacia oleifolia & $1.1 \pm 0.2(3)$ & $27.8 \pm 0.2(2)$ & $0.38 \pm 0.7(2)$ \\
\hline Hillia parasitica & $13.8 \pm 13.4(6)$ & $17.1 \pm 0.8(6)$ & $2.5 \pm 2.5(6)$ \\
\hline Hyptis sp.1 & $3 \pm 1(11)$ & $23.83 \pm 2.46(13)$ & $0.75 \pm 0.25(11)$ \\
\hline Lepidaploa sp.1 & $0.83 \pm 0.24(10)$ & $20.8 \pm 4.8(10)$ & $0.27 \pm 0.06(10)$ \\
\hline Lessingianthus roseus & $0.18 \pm 0.4(6)$ & $28 \pm 0(3)$ & $0.17 \pm 0.2(6)$ \\
\hline Malvaceae sp.1 & $1.8 \pm 1.4(11)$ & $25.3 \pm 2.6(9)$ & $0.63 \pm 0.2(9)$ \\
\hline Paliavana sericiflora & $24.1 \pm 18.9(8)$ & $15.2 \pm 2.8(8)$ & $3.6 \pm 3.9(8)$ \\
\hline Pilosocereus aurisetus aurisetus & $260(1)$ & 16 & $43.54(1)$ \\
\hline Piptolepis cf. leptospermoides & - & - & - \\
\hline Psychotria vellosiana & $4.81 \pm 0.6(11)$ & $34.34 \pm 5.99(10)$ & $1.93 \pm 0.46(10)$ \\
\hline Trixis vauthieri & $0.5 \pm 0(2)$ & $20 \pm 0(2)$ & $0.11 \pm 0$ \\
\hline Vochysia emarginata & $1.08 \pm 0.97(6)$ & - & - \\
\hline Vochysia microphylla & - & - & - \\
\hline Vriesea medusa & $140(1)$ & $17(1)$ & $25.03(1)$ \\
\hline
\end{tabular}


four species $(8 \%)$ presented intermediate attributes between chiropterophily and ornithophily syndrome, one (2\%) species was chiropterophilous and one (2\%) species was sphingophilous (Appendix 1).

The TCR (typical campos rupestres) showed the greatest number of species visited $(\mathrm{N}=37,42 \%$ of ornithophilous species and $58 \%$ of non-ornithophilous species), followed by the OPF (open fields) ( $N=18 ; 39 \%$ of ornithophilous and $61 \%$ of non-ornithophilous species) and CAM (capões de mata $)(\mathrm{N}=17 ; 47 \%$ of ornithophilous and $53 \%$ of nonornithophilous species). Twenty species were exclusive to the area of TCR, whereas six species were exclusive to CAM and OPF, respectively. Only four species were common to the three vegetation types (Aechmea lamarchei $\mathrm{Mez}$ - Bromeliaceae, Eremanthus erytropappus (DC.) MacLeish - Asteraceae, Lepidaploa sp. 1 - Asteraceae and Psychotria vellosiana Benth. - Rubiaceae) (Appendix 1).

The species visited by hummingbirds were distributed among 41 genera and 20 families. The Asteraceae (10 species, $19.6 \%$ ) and Bromeliaceae (10 species, 19.6\%) families represented the most visited species. The other families were represented by four, two or one species (Appendix 1).

More than one third of the species (43\%) visited by the hummingbirds in the study area were endemic to the Espinhaço Range. Eight species were classified in the list of endangered species in Minas Gerais (Minas Gerais, 1997) and/or Brazil (Brasil, 2008). Three of these species (Chronopappus bifrons (DC. ex Pers.) DC. - Asteraceae, Piptolepis leptospermoides (Mart. ex DC.) Sch. Bip. Asteraceae and Pilosocereus aurisetus (Werderm.) Byles and G.D. Rowley - Cactaceae) are considered to be critically endangered (Appendix 1).

\subsection{Characteristics of plants visited by hummingbirds}

Most of the species visited by the hummingbirds $(55 \%)$ were shrubs. Only one species was a tree, another was a vine shrub, and $41 \%$ of the species $(\mathrm{N}=21)$ were herbs. Four herbs were exclusive epiphytes, and another four were exclusive lithophytes (Table 1). Many of the visited species had bracts or petals of bright colours, such as lilac (17.6\%), yellow (19.6\%), red (13.7\%) or pink $(19.6 \%)$, but flowers with colours less attractive for hummingbirds, such as white (17.6\%) and green (5.8\%), were also visited (Appendix 1). Most of the species visited $(84.3 \%)$ presented tubular flowers, with a highly variable mean corolla length among these species. A smaller corolla length $(4.4 \pm 1.1 \mathrm{~mm})$ was observed in the entomophilous species Lessingianthus roseus (Mart. ex DC.) H. Rob. (Asteraceae), and a larger corolla length $(49 \pm 5.65 \mathrm{~mm})$ was observed in the ornithophilous species Rhodophiala cipoana Ravenna (Amaryllidaceae). The mean diameter of the corolla also varied widely among species, measuring $0.75 \pm 0.35 \mathrm{~mm}$ in the entomophilous species Trixis vauthieri DC. (Asteraceae) and $25.1 \pm 2.5 \mathrm{~mm}$ in the Paliavana sericiflora (Gesneriaceae; Appendix 1).

The mean number of open flowers per individual per day ranged from $1 \pm 0$ in $R$. cipoana to $1006 \pm 2018$ in
E. erythropappus and was significantly higher in the nonornithophilous species $(\mathrm{p}=0.046, \mathrm{~N}=50)$ (Appendix 1).

The nectar production was highly variable between the species visited (Table 1). Some species (Eremanthus crotonoides, E. erythropappus and P. leptospermoides Asteraceae; Gaylussacia brasiliensis (Spreng.) Meisn. and G. hispida DC. - Ericaceae; Erythroxylum vaccinifolium Mart. - Erythroxylaceae; and Vochysia microphylla G. Shimizu and K. Yamamoto - Vochysiaceae) produced small nectar amounts that were difficult to measure with the collection method used. Among species in which it was possible to obtain these measurements, the mean nectar volume ranged from $0.5 \pm 0 \mu$ in entomophilous T. vauthieri to $260.0 \pm 0 \mu \mathrm{l}$ in $P$. aurisetus species with intermediate attributes between chiropterophily and ornithophily syndromes.

The mean sugar concentration ranged from $13.7 \pm 0.38 \%$ in the chiropterophilous species Encholirium subsecundum (Baker) Mez (Bromeliaceae) to $44.6 \pm 4.6 \%$ in the ornithophilous species Neoregelia bahiana (Ule) L.B. $\mathrm{Sm}$. (Bromeliaceae), and the mean volume of sugar in the nectar varied from $0 \pm 0.11 \mathrm{mg}$ in $T$. vauthieri to 43.54 $\mathrm{mg}$ in P. aurisetus (Table 1). The mean nectar volume $(\mathrm{p}=0.71)$, the mean sugar concentration $(\mathrm{p}=0.67)$ and the mean volume of sugar in the nectar $(p=0.48)$ were similar between non-ornithophilous and ornithophilous species (Table 1).

\subsection{Flowering seasonality}

The flowering phenology at the population level of most of the species visited by the hummingbirds (69\%) showed annual or supra-annual patterns with an intermediate duration of one to five months (sensu Newstrom et al., 1994), during which seven of these species, which flowered for only one month, potentially represented annual or supraannual patterns with brief flowering (sensu Newstrom et al., 1994). The other species showed continual patterns with flowering periods longer than five months (Figure 2).

The ornithophilous species Hololepis pedunculata (DC. ex Pers.) DC. (Asteraceae), Nematanthus strigillosus (Mart.) H.E. Moore (Asteraceae) and Stachytarpheta mexiae Moldenke (Verbenaceae) were among the species with longer periods of flowering, and the non-ornithophilous species L. roseus and P. leptospermoides had flowering periods lasting nearly an entire year (Figure 2).

Throughout the period of study, ornithophilous and nonornithophilous resources were available to the hummingbirds. In 2008, the first year of the study, the largest number of flowering species was recorded from March to July, and in 2009 , the second year, the largest number was recorded from March to May (Figure 2). The number of flowering species per month differed among the vegetation types (ANOVA: $\mathrm{F}_{2,69}=30.492, \mathrm{p}<0.001$ ), with the highest number observed in the TCR $(9 \pm 3.3, \mathrm{~N}=24)$, followed by the OPF $(5.6 \pm 3, \mathrm{~N}=24, \mathrm{P}=0.000)$ and the CAM $(2.7 \pm 1.6, \mathrm{~N}=24, \mathrm{p}=0.000)$ (Figure $3 \mathrm{~A}$ ).

The flower density in the ornithophilous and nonornithophilous species was similar $(U=220, p=0.161)$. 


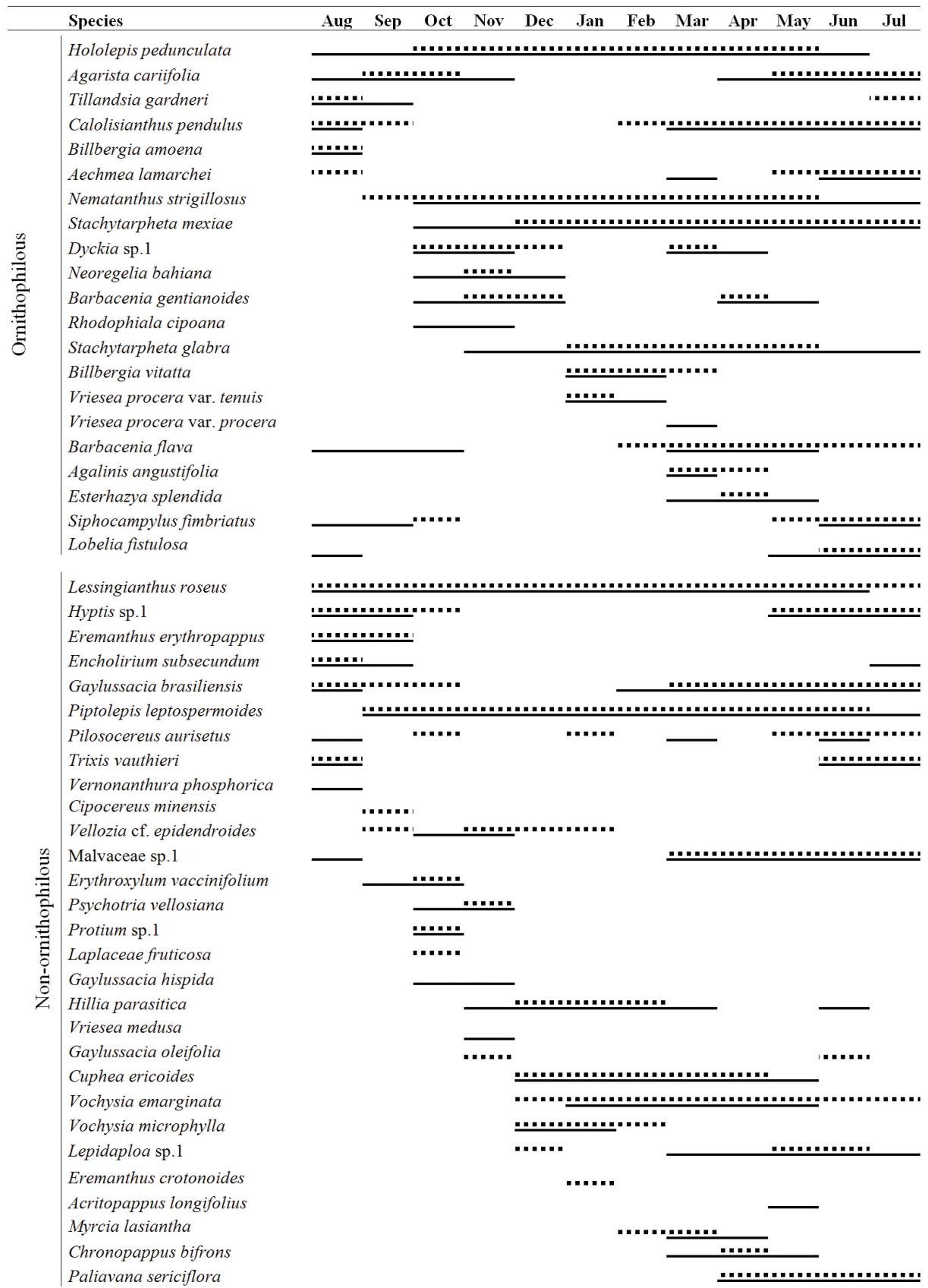

Figure 2. Flowering seasons of plant species visited by the hummingbirds in the first year (August 2007 to July 2008, dotted lines) and second year (August 2008 to July 2009, solid lines) during the study at the Alto do Palácio, Serra do Cipó National Park, MG, southern Brazil.

Higher densities in the ornithophilous flowers were recorded from January to April and August 2008 and from February to March 2009, while the highest densities in the non-ornithophilous flowers were recorded in August 2007 and August and October 2008 (Figure 4). The total flower densities differed among the vegetation types (ANOVA: $\left.\mathrm{F}_{2,69}=3.921, \mathrm{p}=0.024\right)$, with the higher densities in the $\mathrm{CAM}(0.28 \pm 3.41, \mathrm{~N}=24)$ than in the OPF $(0.017 \pm 0.03$,
$\mathrm{N}=24, \mathrm{p}=0.025)$ and similar densities observed between the TCR $(0.165 \pm 0.259, \mathrm{~N}=24)$ and the CAM $(\mathrm{p}=0.815)$ and between the TCR and the OPF $(\mathrm{p}=0.105)$ (Figure 3B).

\subsection{Hummingbird visits}

Although 13 species of hummingbirds were recorded in the AP during the study period (Rodrigues, 2011), only six species visited flowers. Of these, five species belonged to 

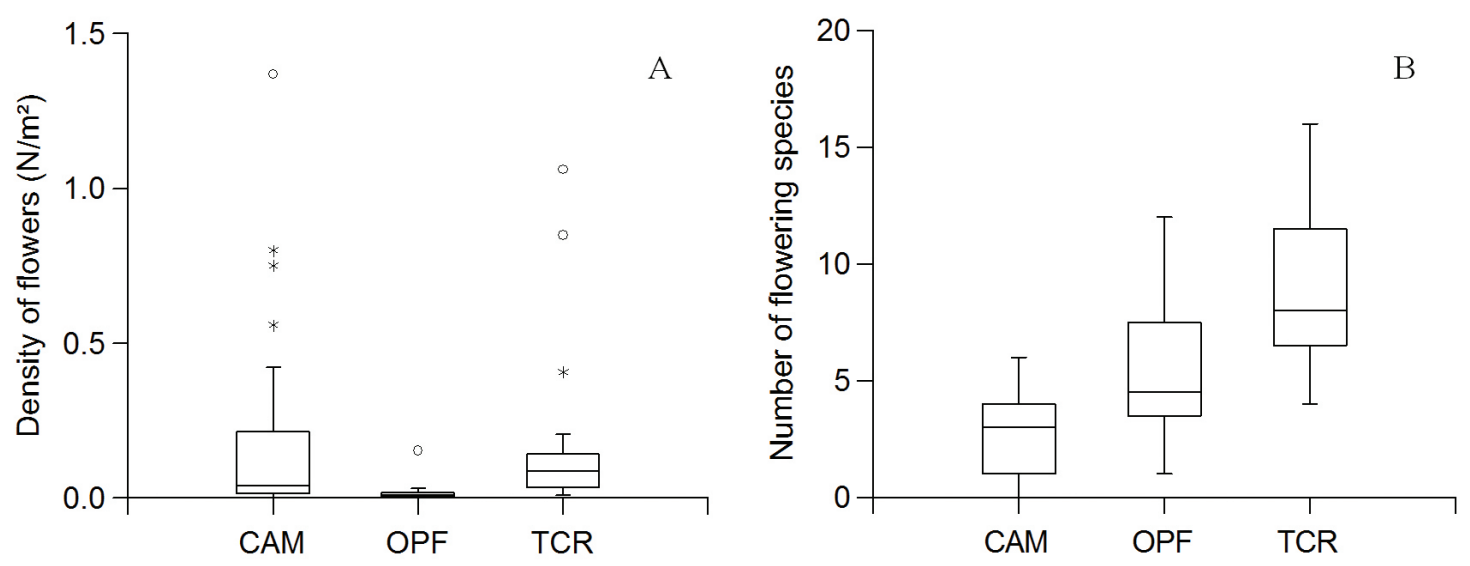

Figure 3. $\log (\mathrm{N}=1)$ of total density of flowers per month and total number of flowering species per month over the study period in the capões de mata (CAM), open fields (OPF) and typical campos rupestres (TCR) sampled at Alto do Palácio, Serra do Cipó National Park, MG, southern Brazil.

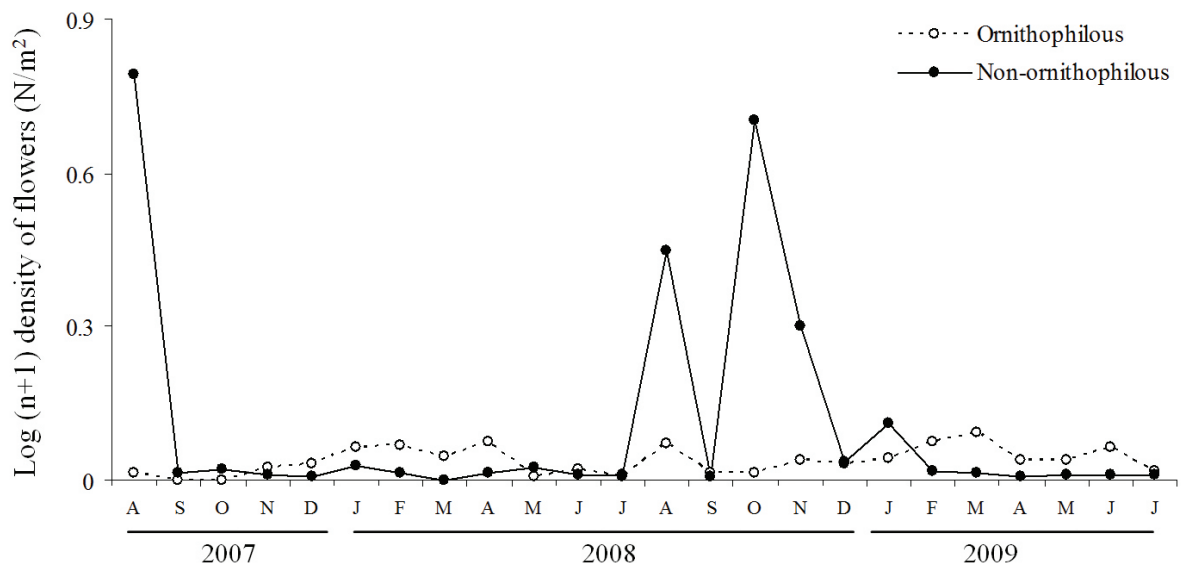

Figure 4. Density of the ornithophilous and non-ornithophilous plant species at Alto do Palácio, Serra do Cipó National Park, MG, southern Brazil.

the Trochilinae subfamily: Augastes scutatus (Temminck, 1824), Campylopterus largipennis (Boddaert, 1783), Colibri serrirostris (Vieillot, 1816), Chlorostilbon lucidus (Shaw, 1812) and Eupetomena macroura (Gmelin, 1788); and one species belonged to the Phaethornithinae subfamily: Phaethornis pretrei (Lesson and Delattre, 1839).

The only plant species that received only illegitimate hummingbird visits was Hillia parasitica Jacq. (Rubiaceae), the flowers of which were visited by the males of A. scutatus. The flowers of $P$. sericiflora also received illegitimate hummingbird visits from the males of $A$. scutatus. Illegitimate hummingbird visits were also recorded in the ornithophilous species Agalinis angustifolia (Mart.) D'Arcy ( $\mathrm{N}=13,50 \%$ of visits) and $N$. strigillosus $(\mathrm{N}=13,12 \%$ of visits), which were visited by the males and females of $A$. scutatus. All of the illegitimate hummingbird visits involved contact with the holes in the base of the corolla of the flowers and/ or buds, in the case of $P$. sericiflora.

Most species of plants (78\%) were visited by only one or two hummingbird species. The ornithophilous species
H. pedunculata was visited by more hummingbird species (Appendix 1). The frequency of hummingbird visits to flowers was similar for the ornithophilous and nonornithophilous species ( $U=4851, p=0191, N=208$ ). The ornithophilous species Lobelia fistulosa Vell. received the highest frequency of visits $(0.02 \pm 0.016$ flowers visited minute $^{-1}$ number of observed flowers ${ }^{-1}$ plant $^{-1}, \mathrm{~N}=8$ ), whereas $P$. aurisetus was the most visited non-ornithophilous species $\left(0.035 \pm 0.022\right.$ flowers visited minute ${ }^{-1}$ number of observed flowers ${ }^{-1}$ plant $^{-1}, \mathrm{~N}=6$ ) (see Appendix 1).

The hummingbirds often visited the flowers in traplines (sensu Feinsinger and Colwell, 1978), that is, shifting through the area in search of resources, visiting flowers at intervals between 10 and 30 minutes and subsequently disappearing from the clumps of flowers after visitation. We observed that only the $C$. serrirostris and the males of $A$. scutatus defended the CAM and TCR territories, respectively. Usually, these species were perched in the same areas and chased other approaching hummingbirds (frequently another individual of the same species). The 
area defended by the males of $A$. scutatus always contained three or more species of flowering plants at the same time.

The number of feeding bouts of hummingbirds increased with the total number of flowers per focal plant observed (ANCOVA: $\mathrm{F}_{1,213}=47.520, \mathrm{p}<0.001$ ). However, the number of hummingbird feeding bouts did not vary among the ornithophilous and non-ornithophilous species (ANCOVA: $\left.\mathrm{F}_{1,213}=1.938, \mathrm{p}=0165\right)$ (Figure 5).

Forty-nine agonistic interactions were recorded between the hummingbirds. Most $(75.5 \%)$ of the interactions were observed between the males of $A$. scutatus. This hummingbird also displaced its females $A$. scutatus $(\mathrm{N}=4)$ and was displaced once by $C$. largipennis and C. serrirostris. Moreover, one agonistic interaction was observed between the females of $A$. scutatus and between the females of $C$. lucidus, and three interactions occurred between the individuals of $C$. serrirostris. The females of C. lucidus displaced P. pretrei once.

\section{Discussion}

\subsection{Richness and composition of plants visited by hummingbirds}

The richness of the hummingbird-visited species in the Alto Palacio (AP) is similar to that reported in studies conducted in six localities of the campos rupestres in the southern area of the Espinhaço Range (53 species; Vasconcelos and Lombardi, 2001). However, the richness is higher than that recorded in the degraded area of the campos rupestres in the southern area of the Espinhaço Range (10 species; Vasconcelos and Lombardi, 1999). This observation might be related to the fact that the campos rupestres of the AP are in a protected area that is adequately preserved and that serves as a refuge for numerous plant species, many of which are endemic and/or threatened.

In the campos rupestres studied by Vasconcelos and Lombardi (1999), many of the plant species might have become extinct because of the degradation of the area caused by mining. Moreover, the richness of hummingbird-visited species in this study is also higher than that recorded in the campos rupestres in the northern area of the Espinhaço Range (36 species; Machado et al., 2007). This observation might be related to the higher number of vegetation types sampled in the AP and the floristic differences between the AP (area of influence of the Atlantic Forest) and the area studied by Machado et al. (2007) (area of influence of the Caatinga biome).

Compared with studies conducted in the lowland habitats in other sites in Brazil, the richness of the hummingbirdvisited species in the AP is similar to that reported in the Atlantic Forest area (50 species; Araujo, 1996). However, this richness is higher than that recorded in the cerrado sites (14 species - Rodrigues and Araujo, 2011; 10 species - Araújo et al., 2011) and in the southern Pantanal (21 species - Araujo and Sazima, 2003) environments with more seasonal relative humidity than in the AP.

Furthermore, the number of ornithophilous species recorded in the AP was lower than that reported in the campos rupestres in the southern region of the Espinhaço Range (32 species), which is probably because of the increased number of areas (six sites) sampled by Vasconcelos and Lombardi (2001) and the methodology used, in which the record of plants visited was obtained by observing the hummingbirds and not by direct observation of the plants.

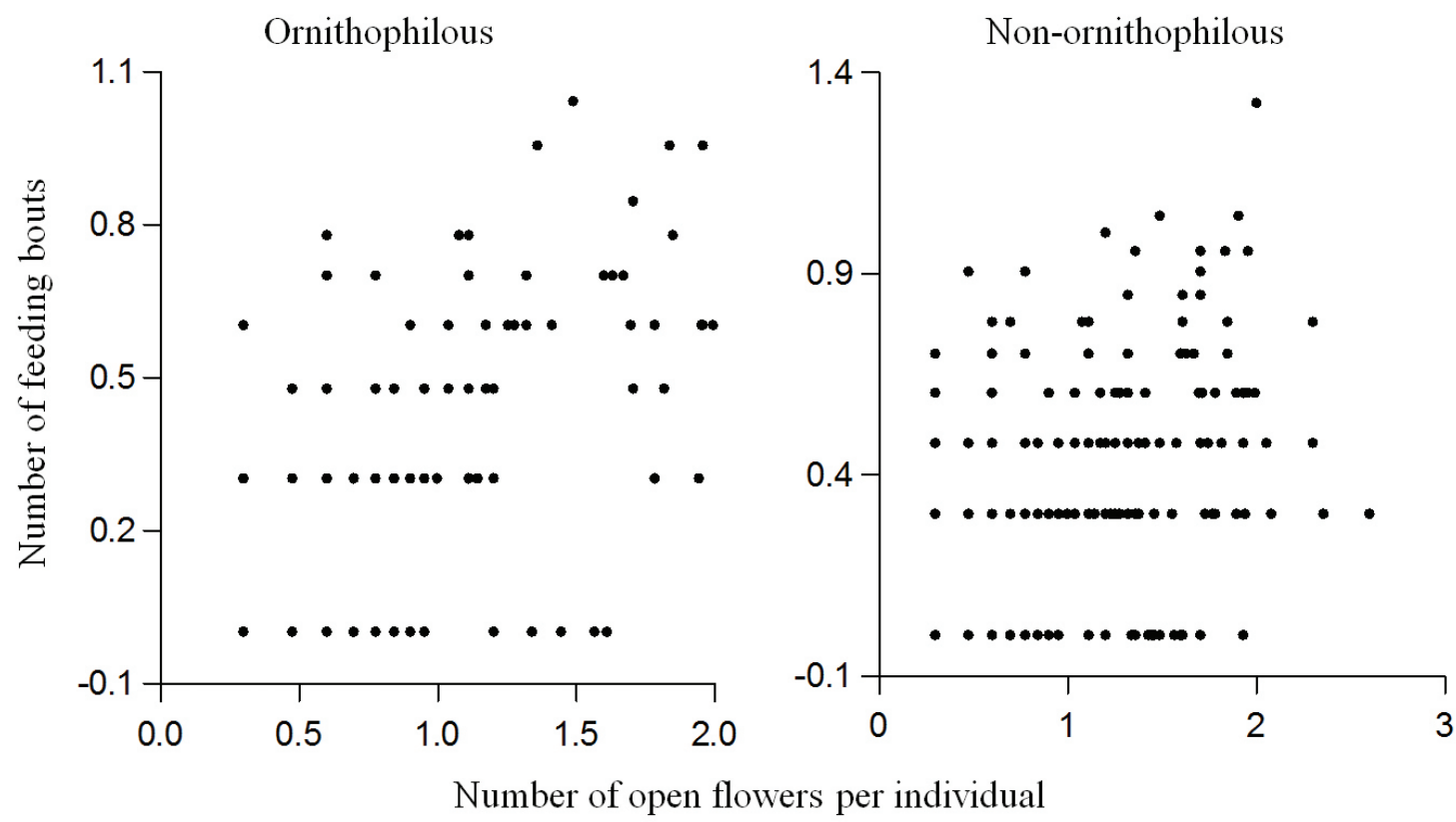

Figure 5. $\log (n+1)$ of the number of feeding bouts relative to $\log (n+1)$ of the number of open flowers per individual of the non-ornithophilous and ornithophilous plant species observed and visited by the hummingbirds at Alto do Palácio, Serra do Cipó National Park, MG, southern Brazil. 
The same pattern recorded for the number of hummingbird-visited species in the AP, when compared with others in the open-habitat mountaintop (Vasconcelos and Lombardi, 1999; Machado et al. 2007), was recorded for the number of ornithophilous species (more species in the AP). The number of ornithophilous species visited by hummingbirds in this study is also higher than that recorded by Freitas and Sazima (2006) (five species) in the campos de altitude in the Serra da Bocaina. Although this open-habitat mountaintop has a high proportion of plant species (see Freitas and Sazima, 2006), it is poor on ornithophilous species. According to Freitas and Sazima (2006), the ornithophilous species constitutes secondary nectar sources for the hummingbirds that usually find their main nectar sources in the surrounding high-altitude forests.

The number of ornithophilous species reported by Freitas and Sazima (2006) in the campos de altitude (five species) is similar to that recorded in the open fields (OPF) of the present study, which seems to be related to the similar floristic characteristics between these habitats.

Moreover, the number of ornithophilous species recorded in the AP was higher than that reported in the other communities of Brazil, such as in the cerrado sites (seven species - Araújo et al., 2011; six species - Rodrigues and Araujo, 2011 and five species - Silberbauer-Gottsberger and Gottsberger, 1988), the Pantanal (six species - Araujo and Sazima, 2003) and the Caatinga (12 species - Machado, 2009). These numbers were likely found because the AP region is influenced by Atlantic Forest vegetation and therefore represents an area of humid campos rupestres. Many plant species are specialised for hummingbird pollination in cold and rainy environments, often prevailing at high elevations (Cruden, 1972; Stiles, 1978; Bleiweiss, 1998; Dalsgaard et al., 2009), primarily because of the endothermic physiology of hummingbirds, which enables the permanence of these pollinators in cold periods at high altitudes (Cruden, 1972; Bleiweiss, 1998).

The proportion of non-ornithophilous species (63.9\%) visited by hummingbirds in this study was similar to that reported in other studies (e.g. Araujo, 1996; Araujo and Sazima, 2003; Machado et al., 2007; Rodrigues and Araujo, 2011). The high proportion of non-ornithophilous species visited by the hummingbirds demonstrates the high degree of generality of these birds concerning the use of floral resources (Araujo and Sazima, 2003; Rodrigues and Araujo, 2011) and their increased memory and exploratory capacity (Pike, 1978; Machado et al., 2007). These characteristics permit this bird group to locate and use resources with features that are frequently inconspicuous and not adapted to hummingbird pollination.

The high degree of richness in the plant species visited by the hummingbirds in the TCR might be related to the complexity of this vegetation type. The TCR has a vegetation complexity that is intermediate between the CAM and the OPF (see Rodrigues and Rodrigues, 2011). As a result, they present rocky outcrops, which allow the occurrence of various plant families including Velloziaceae, Amaryllidaceae, Cactaceae, Bromeliaceae, Asteraceae,
Ericaceae and Orchidaceae (Rapini et al., 2008). Many species of these families (e.g., Amaryllidaceae, Cactaceae, Bromeliaceae, Ericaceae and Orchidaceae) are typically ornithophilous, with all or most of the species being exclusive to this vegetation type.

However, despite the total number of plant species visited by hummingbirds and the higher number of species flowering monthly in the TCR, the flower density was highest in the CAM. The forest vegetation density of the CAM provides a greater vertical stratification for the habitation of many epiphytic ornithophilous species. This fact and the lower area extension of the samples from the CAM probably accounted for the high flower density recorded in this vegetation type.

The CAM had the most dense and humid vegetation types sampled and the greatest proportion of ornithophilous species, mainly epiphytic bromeliads, whereas the OPF contained open vegetation, growing in shallow and dry soil, and hence had the lowest proportion of ornithophilous species. Thus, the differences in the proportion of ornithophilous and non-ornithophilous species between these vegetation types reflects the differences in their floristic composition (Rapini et al., 2008), which are related to the biogeographical and edaphic factors and humidity differences between them.

Although the Asteraceae family is rarely used as a food resource for the hummingbirds in other high and lowland communities (Snow and Teixeira, 1982; Snow and Snow, 1986; Araujo, 1996; Rocca-de-Andrade, 2006; Araujo and Sazima, 2003; Rodrigues and Araujo, 2011; Freitas and Sazima, 2006), in our study site and in the study by Vasconcelos and Lombardi (2001), this family is used mainly by the endemic hummingbird Augastes scutatus. In many localities of campos rupestres in the Espinhaço Range, Asteraceae is one of most representative families, and in the Serra do Cipó, it is the most abundant in species richness (Giulietti et al., 1987). Thus, the use of the Asteraceae species by the hummingbirds in the campos rupestres seems to be related to an association of this abundant resource with $A$. scutatus, the endemic specie of Espinhaço Range (Vasconcelos and Rodrigues, 2010) and abundant hummingbird at this site (Rodrigues, 2011).

\subsection{Characteristics of plants visited by hummingbirds}

The hummingbirds visited many flowers with tubular corollas, but in the AP, the flowers with larger amplitude of corolla length and diameter were visited, as recorded in other studies (Vasconcelos and Lombardi, 2001; Roccade-Andrade, 2006; Rodrigues and Araujo, 2011). This feature appears to be related to the high proportion of non-ornithophilous flowers visited by the hummingbirds, as well as the different bill lengths of these birds in the present study site (Rodrigues, 2011).

The use of pale-coloured flowers by the hummingbirds in the AP also confirms the idea that these birds have an increased memory capacity (Pike, 1978), being able to associate other colours, than bright such as red, yellow and purple, with nectar sources. Moreover, as reported in other studies (Araujo and Sazima, 2003; Rodrigues and 
Araujo, 2011), the characteristics of sugar concentration, nectar volume and the total amount of sugar in nectar were similar among the non-ornithophilous and ornithophilous species. Therefore, the hummingbirds at the AP site also visited pale-coloured non-ornithophilous flowers with nectar offerings similar to those found in the ornithophilous flowers. However, the amount of nectar from the flowers of some plants that the hummingbirds visited in the AP was extremely low, and therefore, it was not possible to collect samples. The low amount of nectar available per flower is probably offset by the high number of flowers per individual in these species (mean $<24$ flowers/ individual). A similar pattern was recorded in the campos rupestres in the northern portion of the Espinhaço Range (Machado et al., 2007).

\subsection{Flowering seasonality}

We found a large overlap of flowering throughout the year among the species visited by the hummingbirds, which was consistent with reports from other high areas (e.g., Vasconcelos and Lombardi, 1999; Machado et al., 2007; Machado, 2009) and lowland areas (e.g., Araujo and Sazima, 2003; Rocca-de-Andrade, 2006). Thus, the nectar availability supports the species of resident hummingbirds at the study site (Rodrigues, 2011). On the other hand, the resident hummingbirds provide a reproductive advantage to the plants as potential pollinators in the area.

Although the density of flowers was similar between the ornithophilous and non-ornithophilous plants, higher densities of ornithophilous flowers were normally recorded between January and April, which is likely related to the rainy season. It seems that these higher densities are a common feature of ornithophilous species in other areas (Sazima et al., 1996; Araujo, 1996; Buzato et al., 2000; Araujo and Sazima, 2003; Rodrigues and Araujo, 2011). However, higher densities of non-ornithophilous flowers were recorded in August and October, and most of the flowering species visited by the hummingbirds were recorded at the end of the rainy season and the start of the dry season. This recording period showed increasing numbers of young Augastes scutatus, the most common hummingbird in the area (Rodrigues and Rodrigues, 2011).

\subsection{Hummingbird visits}

With the exception of $H$. parasitica, which always received illegitimate visits, most species of hummingbirds were able to contact the reproductive parts of the flowers during their visits to the other plants, both ornithophilous and non-ornithophilous, thus indicating that hummingbirds possibly pollinate these plant species. Moreover, during the focal observations, we noted that most of the nonornithophilous species received a low frequency of visits or were not visited by other groups of pollinators. Thus, at Alto Palácio, the hummingbirds are probably acting as effective pollinators of many non-ornithophilous species, as previously observed at other sites (Arizmendi and Ornelas, 1990; Araujo, 1996; Araujo and Sazima, 2003; Rodrigues and Araujo, 2011), where Augastes scutatus was determined to be responsible for the greatest number of non-ornithophilous species visits. However, more detailed data concerning the pollen transfer efficiency of the hummingbirds that forage non-ornithophilous species are necessary and might help demonstrate that hummingbird pollination in neotropical communities is still underestimated and restricted to ornithophilous plants communities (Machado et al., 2007).

The similarity in the frequency of visits by hummingbirds to ornithophilous and non-ornithophilous flowers at the AP site might be explained by the high number of open flowers per individual per day in the entomophilous and mellithophilous species (Araujo and Sazima, 2003; Rodrigues and Araujo, 2011), as well as the nectar offerings at the end and beginning of the day for flowers with intermediate characteristics between the chiropterophilous and ornithophilous syndromes. In addition, the use of these species (chiropterophilous-ornithophilous) by the hummingbirds appears to be common in the campos rupestres of the Espinhaço Range ( $8 \%$ of plants visited by the hummingbirds in this study, $12 \%$ in the campos rupestres of the northern portion of the Espinhaço Range; Machado et al., 2007) compared with other open-habitat mountaintops, such as the campos de altitude (no species; Freitas and Sazima, 2006), the Atlantic Forest (no species; Rocca-de-Andrade, 2006), Pantanal (no species; Araujo and Sazima, 2003) and cerrado sites (no species; Araújo et al., 2011; Rodrigues and Araujo, 2011).

Many hummingbird species are commonly recorded defending feeding territories in the campos rupestres (Vasconcelos and Lombardi, 2001; Jacobi and Antonini, 2008). At our study site, only the $C$. serrirostris and the males of A. scutatus were observed to defend territories and participate in the highest number of agonistic interactions. However, the territories of these observed species might be attributable to the territory defense during the reproductive period (Rodrigues, 2011) and not the amount of floral resources available in the area.

\subsection{Conclusions}

Although some authors initially considered the campos rupestres as a portion of the Cerrado biome (Eiten, 1992; Silva, 1995; 1998), this study demonstrates that the species richness and the number of ornithophilous species visited by the hummingbirds at AP are more similar to hummingbirdplant communities of the Atlantic Forest (Araujo, 1996; Buzato et al., 2000; Rocca-de-Andrade, 2006) than to those of the Cerrado communities (Silberbauer-Gottsberger and Gottsberger, 1988; Araújo et al., 2011; Rodrigues and Araujo, 2011) and other Brazilian highland open-habitat communities (Freitas and Sazima, 2006; Machado et al., 2007). This observation is consistent with the idea that the campos rupestres is a vegetation type apart from Cerrado, occurring in contact zones between the Cerrado, Atlantic Forest and Caatinga biomes (Vasconcelos and Lombardi, 2001; Vasconcelos, 2008; Rodrigues et al., 2011). Therefore, these similarities between the plant 
communities visited by the hummingbirds at the AP and the communities of the Atlantic Forest result from the strong influence of the Atlantic Forest vegetation on Alto do Palácio. Studies such as this, conducted in other areas of the campos rupestres that are influenced by Atlantic Forest, Cerrado and Caatinga vegetation, are necessary to confirm this hypothesis.

As previously reported at other sites (Feinsinger, 1976; Stiles, 1978; Araujo, 1996; Araujo and Sazima, 2003; Rocca-de-Andrade, 2006; Rodrigues and Araujo, 2011), this study showed the hummingbirds use of flower species with characteristics related to pollination by other pollinator groups. These facts support the idea that the combinations of floral traits of real plant species rarely conform to traditional pollination syndromes (Ollerton et al., 2009).

\section{Acknowledgements}

We thank M. L. M. Varela, D. F. Dias, F. C. Diniz and R. Rocha for their help with fieldwork and the ICMBio Institute and the directors of the Serra do Cipó National Park for logistical support. We are grateful to CNPq and Capes for a scholarship awarded to LCR. MR thanks CNPq for financial assistance and the support award (473428/20040 and 300731/2006-0), as well as FAPEMIG (PPM) and the Fundação O Boticário de Proteção a Natureza. We thank A. C. Araujo, M. F. Vasconcelos and C. M. Jacobi for their valuable suggestions concerning the manuscript.

\section{References}

ALVES, RJV. and KOLBEK, J., 2010. Can campo rupestre vegetation be floristically delimited based on vascular plant genera? Plant Ecology, vol. 207, no. 1, p. 67-79. http://dx.doi. org/10.1007/s11258-009-9654-8.

ARAUJO, AC., 1996. Beija-flores e seus recursos florais numa área de planície costeira do litoral norte de São Paulo. Campinas: Universidade Estadual de Campinas. Dissertação de Mestrado.

ARAUJO, AC. and SAZIMA, M., 2003. The assemblage of flowers visited by hummingbirds in the capões of southern Pantanal, Mato Grosso do Sul, Brazil. Flora, vol. 198, no. 6, p. 427-435. http:// dx.doi.org/10.1078/0367-2530-00116.

ARAÚJO, FP., BARBOSA, AAA. and OLIVEIRA, PE., 2011. Floral resources and hummingbirds on an island of flooded forest in Central Brazil. Flora, vol. 206, no. 9, p. 827-835. http://dx.doi. org/10.1016/j.flora.2011.04.001.

ARIZMENDI, MC. and ORNELAS, JF., 1990. Hummingbirds and their floral resources in a tropical dry forest in Mexico. Biotropica, vol. 22 , no. 2 , p. 172-180. http://dx.doi.org/10.2307/2388410.

BAWA, KS., 1990. Plant-pollinator interactions in tropical rain forests. Annual Review of Ecology Evolution and Systematics, vol. 21, no. 1, p. 399-422. http://dx.doi.org/10.1146/annurev. es.21.110190.002151.

BLEIWEISS, R., 1998. Phylogeny, body mass, and genetic consequences of lek-mating behaviour in hummingbirds. Molecular Biology and Evolution, vol. 15, no. 5, p. 492-498. http://dx.doi. org/10.1093/oxfordjournals.molbev.a025948.
BLEIWEISS, R., 2009. The tail end of hummingbird evolution: parallel flight system development in living and ancient birds. Biological Journal of the Linnean Society. Linnean Society of London, vol. 97, no. 3, p. 467-493. http://dx.doi.org/10.1111/j.10958312.2009.01240.x.

Brasil. Ministério do Meio Ambiente, 2008. Instrução Normativa $\mathrm{n}^{\circ}$ 6, de 23 de setembro de 2008. Diário Oficial da República Federativa do Brasil, Brasília, 24 set. Anexo I - Lista Oficial das Espécies da Flora Brasileira Ameaçadas de Extinção.

BUZATO, S., SAZIMA, M. and SAZIMA, I., 2000. Hummingbirdpollinated floras at three Atlantic Forest sites. Biotropica, vol. 32, no. 4b, p. 824-841. http://dx.doi.org/10.1111/j.1744-7429.2000. tb00621.x.

CRUDEN, RW., 1972. Pollinators in high-elevation ecosystems: relative effectiveness of birds and bees. Science, vol. 176, no. 4042, p. 1439-1440. http://dx.doi.org/10.1126/science.176.4042.1439. PMid:17834653

DALSGAARD, B., MARTÍN GONZÁLEZ, AM., OLESEN, JM., OLLERTON, J., TIMMERMANN, A., ANDERSEN, LH. and TOSSAS, AG., 2009. Plant-hummingbird interactions in the West Indies: floral specialisation gradients associated with environment and hummingbird size. Oecologia, vol. 159, no. 4, p. 757-766. http://dx.doi.org/10.1007/s00442-008-1255-z. PMid:19132403

ECHTERNACHT, L., TROVÓ, M., OLIVEIRA, CT. and PIRANI, JR., 2011. Areas of endemism in the Espinhaço Range in Minas Gerais, Brazil. Flora (Jena), vol. 206, no. 9, p. 782-791. http:// dx.doi.org/10.1016/j.flora.2011.04.003.

EITEN, G., 1992. Natural Brazilian vegetation types and their causes. Anais da Acâdemia Brasileira de Ciências, vol. 64, suplemento 1, p. 35-65.

FAEGRI,K. and PIJL,VD., 1980. The principles of pollination ecology. Oxford/New York: Pergamon Press.

FEINSINGER, P., 1976. Organization of a tropical guild of nectarivorous birds. Ecological Monographs, vol. 46, no. 3, p. 257-291. http://dx.doi.org/10.2307/1942255.

FEINSINGER, P., 1983. Coevolution and pollination. In: FUTUYMA, DJ. and SLATKIN, M. (Eds.). Coevolution. Sunderland: Sinauer Associates. p. 282-310.

FEINSINGER, P. and COLWELL, RK., 1978. Community organization among neotropical nectar-feeding birds. American Zoologist, vol. 18, no. 4, p. 779-795.

FREITAS, L. and SAZIMA, M., 2006. Pollination biology in a tropical high-altitude grassland in Brazil: interactions at the community level. Annals of the Missouri Botanical Garden, vol. 93, no. 3, p. 465-516. http://dx.doi.org/10.3417/00266493(2007)93[465:PBIATH]2.0.CO;2.

GALETTO, L. and BERNARDELLO, G., 2005. Rewards in flowers: Nectar. In DAFNI, A., KEVAN, PG. and HUSBAND, BC. (Eds.). Practical Pollination Biology. Cambridge: Enviroquest. p. 261-313

GIULIETTI, AM., MENEZES, NA., PIRANI, JR., MEGURO, M. and WANDERLEY, MGL., 1987. Flora da Serra do Cipó: caracterização e lista das espécies. Boletim de Botânica da USP, vol. 9, no. 0, p. 1-151. http://dx.doi.org/10.11606/issn.2316-9052. v9i0p1-151.

GIULIETTI, AM., PIRANI, JR. and HARLEY, RM., 1997. Espinhaço Range region, eastern Brazil. In: DAVIS, SD., HEYWOOD, VH., HERRERA-MACBRYDE, O., VILLA-LOBOS, J. and 
HAMILTON, AC. (Eds.). Centres of plant diversity: a guide and strategy for their conservation. Oxford: Information Press. p. 397-404.

JACOBI, CM. and ANTONINI, Y., 2008. Pollinators and defence of Stachytarpheta glabra (Verbenaceae) nectar resources by the hummingbird Colibri serrirostris (Trochilidae) on ironstone outcrops in south-east Brazil. Journal of Tropical Ecology, vol. 24, no. 03, p. 301-308. http://dx.doi.org/10.1017/S0266467408005051.

MACHADO, CG., 2009. Beija-flores (Aves: Trochilidae) e seus recursos florais em uma área de caatinga da Chapada Diamantina, Bahia, Brasil. Zoologia, vol. 26, no. 2, p. 255-265. http://dx.doi. org/10.1590/S1984-46702009000200008.

MACHADO, CG., COELHO, AG., SANTANA, CS. and RODRIGUES, M., 2007. Beija-flores e seus recursos florais em uma área de campo rupestre da Chapada Diamantina, Bahia. Revista Brasileira de Ornitologia, vol. 15, p. 267-279.

MACHADO, CG. and ROCCA, MA., 2010. Protocolos para o estudo de polinização por Aves. In VON MATTER, S., STRAUBE, F., ACCORDI, I., PIACENTINI, V. and CÂNDIDO-JUNIOR, EJF. (Orgs.). Ornitologia e Conservação: Ciência Aplicada, Técnicas de Pesquisa e Levantamento de Aves. Rio de Janeiro: Technical books.

MACHADO, IC. and LOPES, AV., 2004. Floral traits and pollination systems in the Caatinga, a Brazilian tropical dry forest. Annals of Botany, vol. 94, no. 3, p. 365-376. http://dx.doi.org/10.1093/ aob/mch152. PMid: 15286010

Minas Gerais. Secretaria Secretaria de Estado de Meio Ambiente e Desenvolvimento Sustentável - SEMAD, 1997. Deliberação COPAM $n^{\circ} 85$, de 21 de outubro de 1997. Diário do Executivo, Minas Gerais, 30 out. Anexo I - Lista das Espécies Ameaçadas de Extinção da Flora do Estado de Minas Gerais.

NEWSTROM, LE., FRANKIE, GW. and BAKER, HG., 1994. A new classification for plant phenology based on flowering patterns in lowland tropical rain forest trees at La Selva, Costa Rica. Biotropica, vol. 26, no. 2, p. 141-159. http://dx.doi. org/10.2307/2388804

OLLERTON, J., ALARCÓN, R., WASER, NM., PRICE, MV., WATTS, S., CRANMER, L., HINGSTON, A., PETER, CI. and ROTENBERRY, J., 2009. A global test of the pollination syndrome hypothesis. Annals of Botany, vol. 103, n. 9, p. 14711480. http://dx.doi.org/10.1093/aob/mcp031. PMid:19218577. PMCid:PMC2701765

PIKE, GH., 1978. Optimal foraging in hummingbirds: testing the marginal value theorem. American Zoologist, vol. 18, p. 739-752.

RAMÍREZ, N., 2004. Ecology of pollination in a tropical Venezuelan savanna. Plant Ecology, vol. 173, no. 2, p. 171-189. http://dx.doi. org/10.1023/B:VEGE.0000029320.34895.7d.

RAPINI, A., RIBEIRO, PL., LAMBERT, S. and PIRANI, JR., 2008. A flora dos campos rupestres da Cadeia do Espinhaço. Megadiversidade, vol. 4, p. 15-23.

ROCCA-DE-ANDRADE, MA., 2006. Recurso floral para aves em uma comunidade de Mata Atlântica de encosta: sazonalidade e distribuição vertical. Campinas: Universidade Estadual de Campinas. 118 p. Tese de doutorado em Biologia Vegetal.

RODRIGUES, LC., 2011. Beija-flores e seus recursos florais em uma área de campo rupestre: composição de espécies, sazonalidade e rede de interações. Belo Horizonte: Universidade Federal de Minas Gerais. 118 p. Tese de doutorado em Ecologia, Conservação e Manejo da Vida Silvestre.
RODRIGUES, LC. and ARAUJO, AC., 2011. The hummingbird community and their floral resources in an urban forest remnant in Brazil. Brazilian Journal of Biology, vol. 71, no. 3, p. 611-622. PMid:21881784.

RODRIGUES, LC. and RODRIGUES, M., 2011. Size dimorphism, juvenal plumage, and timing of breeding of the Hyacinth Visorbearer (Augastes scutatus).The Wilson Journal of Ornithology, vol. 123, no. 4, p. 726-733. http://dx.doi.org/10.1676/11-042.1

RODRIGUES, M., FREITAS, GHD., COSTA, LM., DIAS, DF., VARELA, MLM. and RODRIGUES, LC., 2011. Avifauna, Alto do Palácio, Serra do Cipó National Park, state of Minas Gerais, southeastern Brazil. Check List, vol. 7, p. 151-161.

RODRIGUES, M., CARRARA, LA., FARIA, LP. and GOMES, HB., 2005. Aves do Parque Nacional da Serra do Cipó: o vale do Rio Cipó, Minas Gerais, Brasil. Revista Brasileira de Zoologia, vol. 22, no. 2, p. 326-338. http://dx.doi.org/10.1590/S010181752005000200005 .

SAFFORD, HD., 1999. Brazilian páramos i. an introduction to the physical environment and vegetation of the campos de altitude. Journal of Biogeography, vol. 26, no. 4, p. 693-712. http://dx.doi. org/10.1046/j.1365-2699.1999.00313.x.

SANMARTIN-GAJARDO, I. and SAZIMA, M., 2005. Chiropterophily in Sinningieae (Gesneriaceae): Sinningia brasiliensis and Paliavana prasinata are bat-pollinated, but P. sericiflora is not. Not yet? Annals of Botany, vol. 95, no. 7, p. 1097-1103. http://dx.doi.org/10.1093/aob/mci124. PMid:15797896

SAZIMA, I., BUZATO, S. and SAZIMA, M., 1996. An assemblage of hummingbird-pollinated flowers in a montane forest in southeastern Brazil. Botanica Acta, vol. 109, no. 2, p. 149-160. http://dx.doi.org/10.1111/j.1438-8677.1996.tb00555.x.

SAZIMA, M., SAZIMA, I. and BUZATO, S., 1994. Nectar by day and night: Siphocampylus sulfureus (Lobeliaceae) pollinated by hummingbirds and bats. Plant Systematics and Evolution, vol. 191, no. 3-4, p. 237-246. http://dx.doi.org/10.1007/BF00984668.

SILBERBAUER-GOTTSBERGER, I. and GOTTSBERGER, G., 1988. A polinização de plantas do cerrado. Brazilian Journal of Biology, vol. 48, p. 651-663.

SILVA, JMC., 1995. Biogeographic analysis of the South American Cerrado avifauna. Steenstrupia (Copenhagen), vol. 21, p. 49-67.

SILVA, JMC., 1998. Integrating biogeography and conservation: an example with birds and plants of the Cerrado region. Anais $d a$ Academia Brasileira de Ciencias, vol. 70, p. 881-888.

SILVA, JM. and BATES, JM., 2002. Biogeographic patterns and conservation in the South American Cerrado: a tropical savanna Hotspot. Bioscience, vol. 52, no. 3, p. 225-233. http://dx.doi. org/10.1641/0006-3568(2002)052[0225:BPACIT]2.0.CO;2.

SNOW, DW. and SNOW, BK., 1986. Feeding ecology of hummingbirds in the Serra do Mar, southeastern Brazil. El Hornero, vol. 12, p. 286-296

SNOW, DW. and TEIXEIRA, DI., 1982. Hummingbirds and their flowers in the coastal mountains of southeastern Brazil. Journal fur Ornithologie, vol. 123, no. 4, p. 446-450. http:// dx.doi.org/10.1007/BF01643279.

STILES, FG., 1978. Temporal organization of flowering among the hummingbird food plants of a tropical wet forest. Biotropica, vol. 10, no. 3, p. 194-210. http://dx.doi.org/10.2307/2387905. 
STOTZ, DF., FITZPATRICK, JW., PARKER III, TA. and MOSKOVITS, DK., 1996. Neotropical birds: ecology and conservation. Chicago: University of Chicago Press.

VASCONCELOS, MF., 2008. Mountaintop endemism in eastern Brazil: why some bird species from campos rupestres of the Espinhaço Range are not endemic to the Cerrado region? Revista Brasileira de Ornitologia, vol. 16, p. 348-362.

VASCONCELOS, MF., 2011. O que são campos rupestres e campos de altitude nos topos de montanhas do Leste do Brasil? Revista Brasileira de Botânica, vol. 34, no. 2, p. 241-246.

VASCONCELOS, MF. and LOMBARDI, JA., 1999. Padrão Sazonal de ocorrência de seis espécies de beija-flores (Apodiformes: Trochilidae) em uma localidade de campo rupestre na Serra do Curral, Minas Gerais. Ararajuba, vol. 7, p. 71-79.
VASCONCELOS, MF. and LOMBARDI, JA., 2001. Hummingbirds and their flowers in the campos rupestres of southern Espinhaço Range, Brazil. Melopsittacus, vol. 4, p. 3-30.

VASCONCELOS, MF. and RODRIGUES, M., 2010. Patterns of geographic distribution and conservation of the open-habitat avifauna of southeastern Brazilian mountaintops (campos rupestres and campos de altitude). Papéis Avulsos de Zoologia, vol. 50, p. 1-29.

WILSON, P., CASTELLANOS, MC., HOGUE, JN., THOMSON, JD. and ARMBRUSTER, WS., 2004. A multivariate search for pollination syndromes among Penstemons. Oikos, vol. 104, no. 2, p. 345-361. http://dx.doi.org/10.1111/j.0030-1299.2004.12819.x.

WOLF, LL., STILES, FG. and HAINSWORTH, FR., 1976. Ecological organization of a tropical highland hummingbird community. Journal of Animal Ecology, vol. 45, no. 2, p. 349379. http://dx.doi.org/10.2307/3879. 


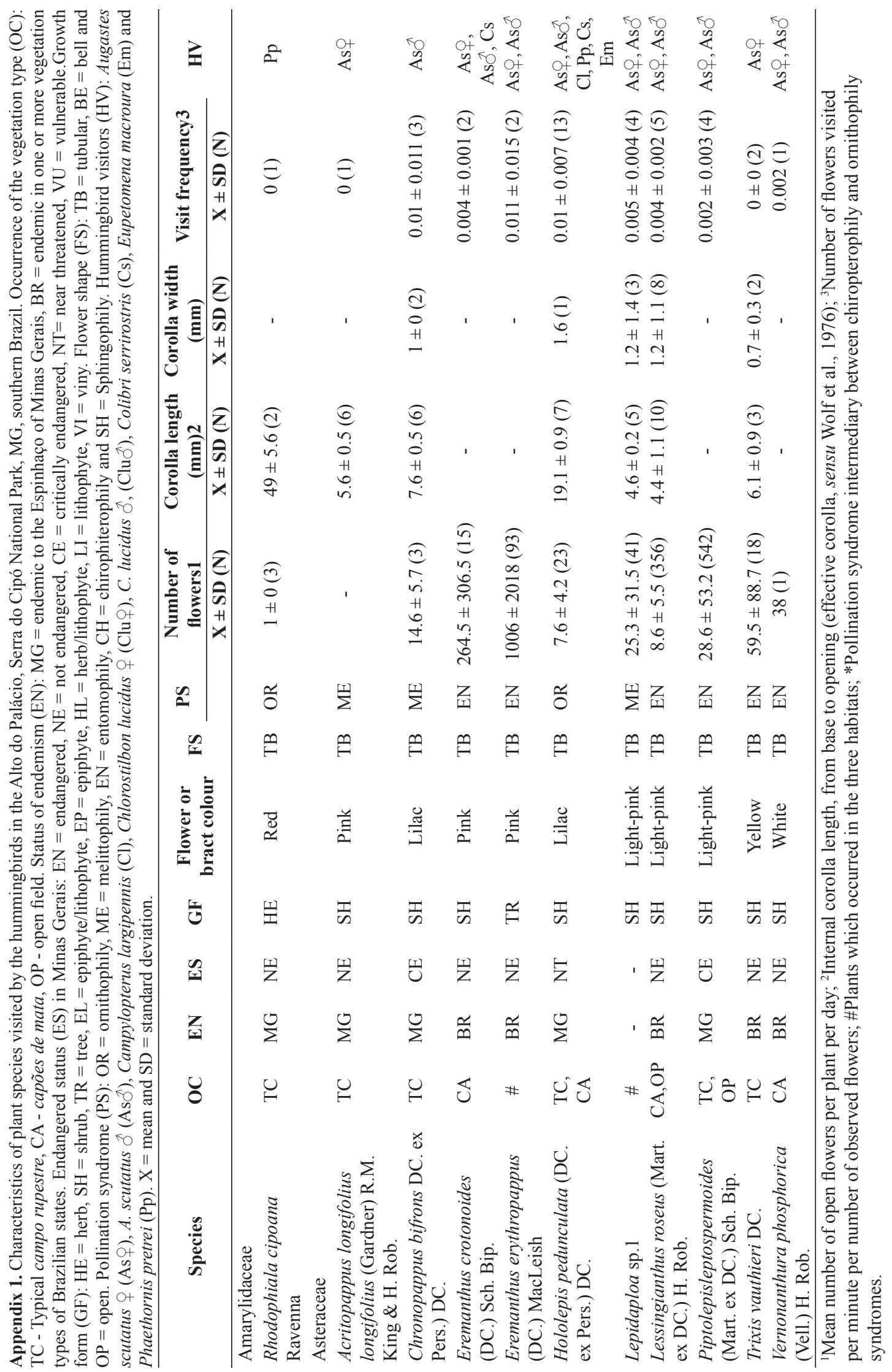




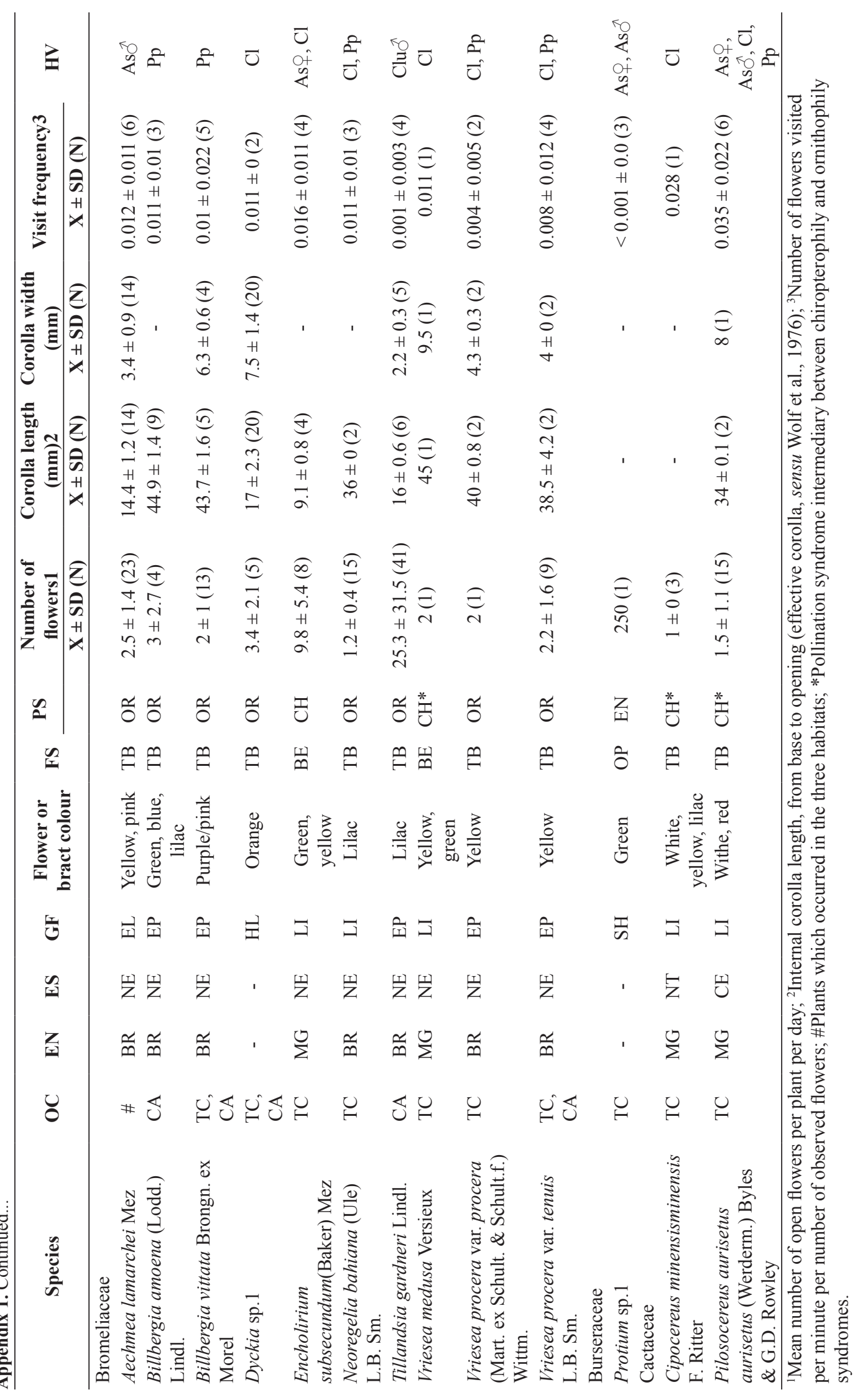




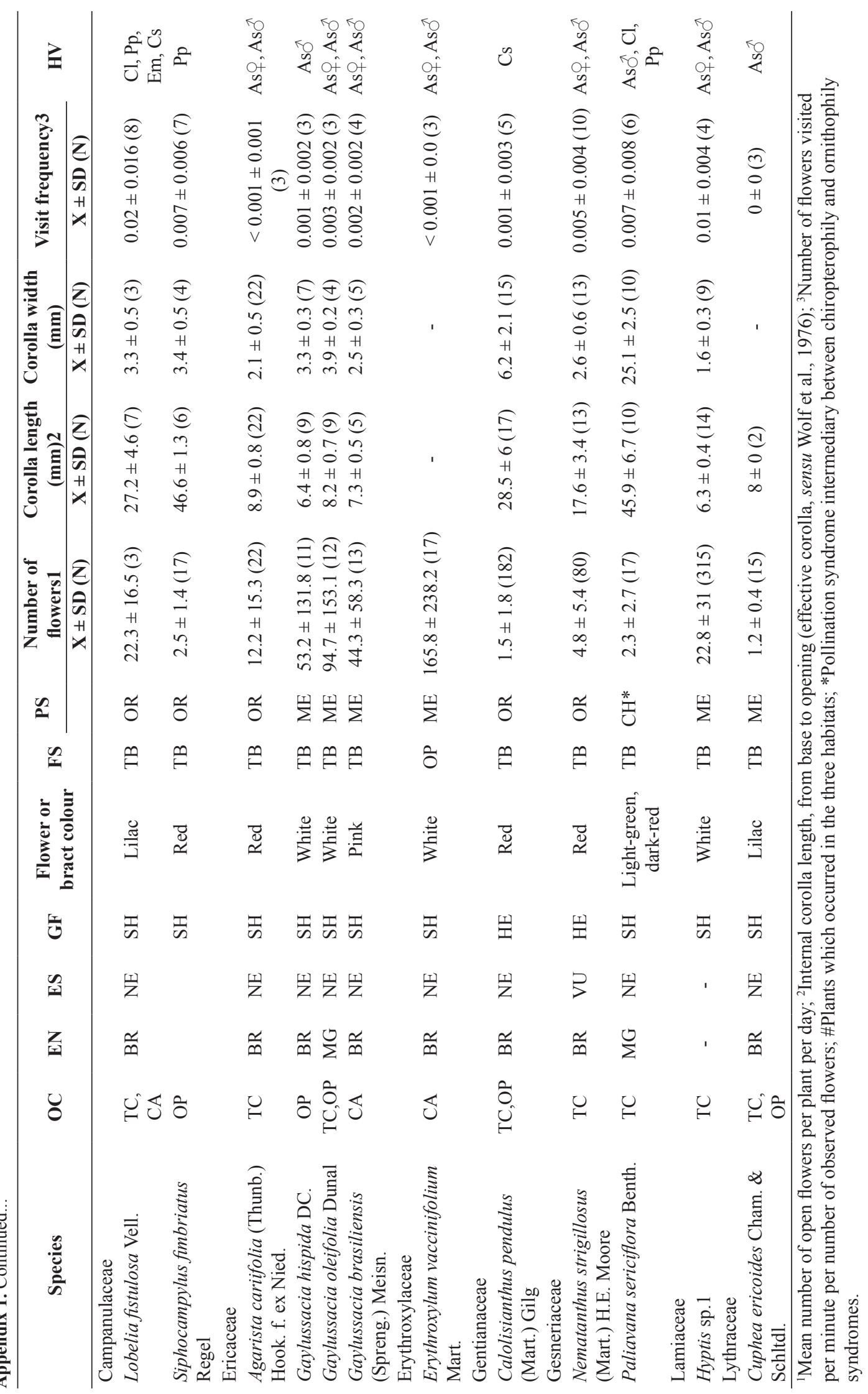




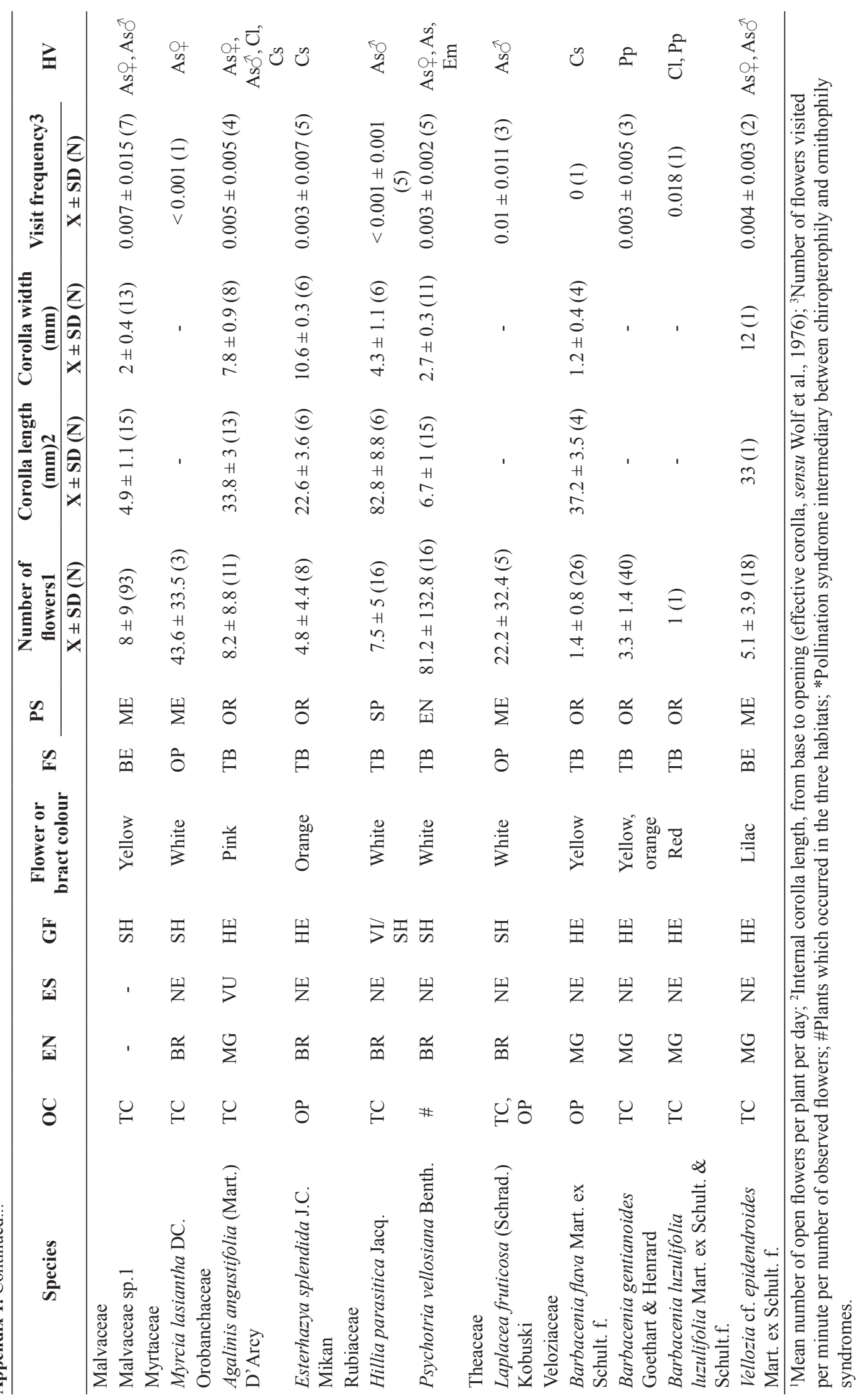


Rodrigues, LC. and Rodrigues, M.

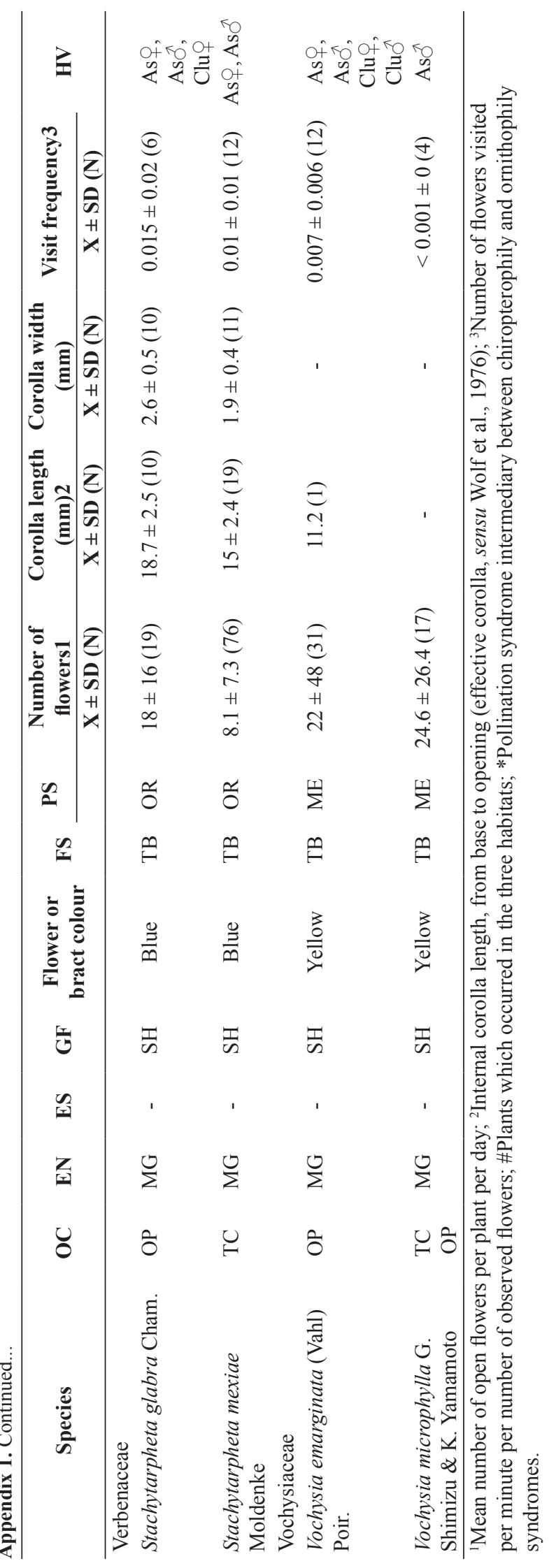

